\title{
Effects of primaquine and chloroquine on oxidative stress parameters in rats
}

\author{
FRANCIANNE GIOVANELLA ${ }^{1,2,3}$, GABRIELA K. FERREIRA ${ }^{1,2,3}$, SAMIRA D.T. DE PRÁ ${ }^{1,2,3}$, MILENA \\ CARVALHO-SILVA ${ }^{1,2,3}$, LARA M. GOMES ${ }^{1,2,3}$, GISELLI SCAINI ${ }^{1,2,3}$, RENATA C. GONÇALVES ${ }^{2,4}$, MONIQUE \\ MICHELS ${ }^{2,4}$, LETÍCIA S. GALANT ${ }^{2,4}$, LUIZA M. LONGARETTI ${ }^{5}$, ANA LUIZA DAJORI ${ }^{5}$, VANESSA \\ M. ANDRADE ${ }^{5}$, FELIPE DAL-PIZZOL ${ }^{2,4}$, EMILIO L. STRECK $^{1,2,3}$ and RENAN P. DE SOUZA ${ }^{6}$ \\ ${ }^{1}$ Laboratório de Bioenergética, Universidade do Extremo Sul Catarinense, \\ Av. Universitária, 1105, 88806-000 Criciúma, SC, Brasil \\ ${ }^{2}$ Instituto Nacional de Ciência e Tecnologia Translacional em Medicina, Rua Ramiro \\ Barcelos, 2350, Sala 12117, 90035-903 Porto Alegre, RS, Brasil \\ ${ }^{3}$ Núcleo de Excelência em Neurociências Aplicadas de Santa Catarina/NENASC, \\ Av. Universitária, 1105, 88806-000 Criciúma, SC, Brasil \\ ${ }^{4}$ Laboratório de Fisiopatologia Experimental, Programa de Pós-graduação em Ciências da Saúde, \\ Universidade do Extremo Sul Catarinense, Av. Universitária, 1105, 88806-000 Criciúma, SC, Brasil \\ ${ }^{5}$ Laboratório de Biologia Celular e Molecular, Programa de Pós-Graduação em Ciências da Saúde, \\ Universidade do Extremo Sul Catarinense, Av. Universitária, 1105, 88806-000 Criciúma, SC, Brasil \\ ${ }^{6}$ Instituto de Ciências Biológicas, Unidade Federal de Minas Gerais/UFMG. Av. Antonio \\ Carlos, 6227, Pampulha, 31270-901 Belo Horizonte, MG, Brasil
}

Manuscript received on November 24, 2014; accepted for publication on July 15, 2015

\begin{abstract}
Primaquine and chloroquine are used for the treatment of malaria; evidence from the literature suggests that these drugs may induce oxidative stress. In this study we investigated the effects of primaquine and chloroquine on oxidative damage and DNA damage in brain, liver and kidney of rats after 7, 14 and 21 days of administration. Our results demonstrated that primaquine causes DNA damage in brain after 7, 14 and 21 days, and in liver after 7 and 14 days. Moreover, primaquine increases TBARS levels in the kidney and protein carbonyls in the brain after 14 days, and decreases protein carbonyls in the liver after 7 days. Whereas chloroquine causes DNA damage in the kidney after 7 and 14 days, and in the liver after 14 and 21 days, increases TBARS levels in the kidney after 7 days, and decreases TBARS levels in the brain after 21 days. Moreover, decreases protein carbonyls in the liver after 7 and 14 days, and in the brain after 7 and 21 days. However, chloroquine treatment for 14 days increases protein carbonyls in the brain and kidney. In conclusion, these results showed that prolonged treatment with antimalarial may adversely affect the DNA.
\end{abstract}

Key words: primaquine, chloroquine, oxidative damage, DNA damage, antimalarial drugs.

\section{INTRODUCTION}

Malaria is a life-threatening parasitic disease of epidemic proportions caused in humans by parasites of the Plasmodium species through the bite of infected anopheles mosquitoes, and it is a major

Correspondence to: Emilio Luiz Streck

E-mail: emiliostreck@gmail.com public health concern for developing countries. Each year malarial infection is responsible for an estimated 300 to 500 million acute illnesses and 2 million deaths in tropical and subtropical regions worldwide. In the 2013 malaria report, the number of malaria cases exceeded 200 million, with more than 600,000 deaths (Kain and Keystone 
1998, WHO 2013), and the severity of malaria is exacerbated by resistant strains of Plasmodium and lack of effective vaccines and drugs (NaBangchang and Karbwang 2009).

Malaria control requires an integrate approach, including prevention (primarily vector control) and prompt treatment with effective antimalarials (Staines and Krishna 2012). Primaquine (PQ) and chloroquine (CQ) are the two widely used antimalarials in the tropical regions of the world (Thabrew et al. 1985, WHO 2013). These drugs are used not only for the treatment of malaria but also for the prevention and prophylaxis, as well as for treatment of other diseases (Leslie 1990). Although these drugs belong to the quinoline group, their mode of action and the stage of Plasmodium at which they act differs. One common property of the two drugs is that they accumulate in the Plasmodium and the cells, which harbor the parasite (De Duve et al. 1974, Foley and Tilley 1998).

CQ acts by inhibiting hemozoin biocrystallization, which gives rise to toxic free heme accumulation that is responsible for the death of the parasites (Barennes et al. 2006). It is well tolerated and has been administered as a standard therapy for decades (Bray and Ward 1993, Solomon and Lee 2009). CQ has remained the mainstay of therapeutic and prophylactic regimens available in most malaria-endemic Third World countries because it is cheaper and more readily available than other antimalarials. Availabe data show that chloroquine is concentrated in the liver and many other tissues following its administration (Adelusi and Salako 1982). In toxic doses, it is known to cause appreciable cellular damage to liver, kidney and heart muscle (deGroot et al. 1981, Ngaha 1982).

$\mathrm{PQ}$, the prototype 8 -aminoquinoline tissue schizontocide, is effective against all four malarial species that infect humans and is the only drug approved for the radical cure of relapsing malaria (Baird et al. 2003). As resistance has developed from extensive use of blood schizontocides, such as CQ, the importance of PQ in combating multiple drug resistance has increased, and it is now used in combination with several blood schizontocides for the treatment and prophylaxis of all forms of malaria, including the most lethal malarial species, Plasmodium falciparum (Shanks et al. 2001). The hemolytic activity of PQ has long been known to be due to an intraerythrocytic oxidative stress that is mediated by redox-active metabolites rather than by the parent drug itself. The oxidatively damaged erythrocytes are thought to be recognized by splenic macrophages as the equivalent of senescent red cells, resulting in their selective removal from the circulation (Rifkind 1966). 5-Hydroxyprimaquine (5-HPQ) is a putative human metabolite of PQ that forms a redox pair with its quinoneimine form; continuous cycling of this redox pair is thought to generate reactive oxygen species (ROS) within erythrocytes (Vasquez-Vivar and Augusto 1992).

Earlier studies have indicated that antimalarials such as CQ and PQ inhibit cytochrome P450 mediated mixed function oxidase activities both in vivo and in vitro (Back et al. 1983, Emerole and Thabrew 1983, Murray 1984, Thabrew and Ioannides 1984) and lead to oxidative stress, particularly in erythrocytes (Bolchoz et al. 2002, Baird and Hoffman 2004, Becker et al. 2004). It has been shown that heme, generated by QC, is a potentially damaging species, which can directly attack and may impair intracellular targets including the lipid bilayer, the cytoskeleton, intermediary metabolic enzymes, and DNA (Wagener et al. 2003). Also, there are available reports indicating that high levels of free heme cause severe toxic effects to kidney, liver, central nervous system and cardiac tissue and that free heme catalyzes the oxidation, covalent cross-linking and aggregate formation of protein and its degradation to small peptides (Kumar and Bandyopadhyay 2005). One study has shown that CQ causes increased lipid peroxidation and decreased antioxidant enzyme activities in the retina of rat (Bhattacharyya et al. 1983). It has also been shown that CQ and other 4-aminoquinolines adversely affect lysosomal function (Mackenzie 1990, Slater 1993). Srivastava 
et al. (1993) showed that PQ at the low dose caused significant inhibition of the antioxidant defence system (superoxide dismutase and catalase activity) and induced higher levels of superoxide and lipid peroxides. Summerfield and Tudhope (1978) demonstrated that PQ in vitro increase the formation of superoxide radicals. Moreover, 5-hydroxyprimaquine, a metabolite of primaquine, causes a prolonged generation of ROS within erythrocytes (Bowman et al. 2005).

Considering that the PQ and CQ may promote oxidative stress by decreasing non-enzymatic and enzymatic antioxidant defenses, changing the redox state and stimulating oxidative damage to DNA in brain of rats, the main objective of this study was to investigate the effects of PQ and CQ on oxidative damage and DNA damage in brain, liver and kidney of rats after 7, 14 and 21 days of administration.

\section{MATERIALS AND METHODS}

\section{ANIMALS}

Sixty-three male Wistar rats were obtained from the Central Animal House of the Universidade do Extremo Sul Catarinense. All rats were caged in groups of five with free access to food and water and were maintained on a 12-h light-dark cycle (lights on 7:00 am) at a temperature of $23 \pm 1{ }^{\circ} \mathrm{C}$. All experimental procedures were carried out in accordance with the National Institutes of Health Guide for the Care and Use of Laboratory Animals and the Brazilian Society for Neuroscience and Behavior recommendations for animal care with the approval of the Ethics Committee of the Universidade do Extremo Sul Catarinense (protocol number 107/2012).

\section{ADMINISTRATION OF CHLOROQUINE AND PRIMAQUINE}

Two antimalarial drugs were used in this study: chloroquine and Primaquine. Adult male Wistar rats (60 days old) were intraperitoneal administered with PQ (0.21 mg/kg) and CQ (10 mg/kg) dissolved in saline solution $(0.85 \%)$ in a volume of $1 \mathrm{~mL} / \mathrm{kg}$, once a day for 7, 14 and 21 days ( $n=7$ per group) (Leslie 1990, Thabrew et al 1985). Control group received an equal volume of saline solution $(\mathrm{NaCl}$ $0.85 \%$ ). Drug solutions were daily prepared before the administration.

\section{TISSUE PREPARATION}

Two hours after the last injection the rats were sacrificed by decapitation without anesthesia and the brain, liver and kidney were immediately removed and dissected on a glass dish over ice. For comet assay the brain, liver and kidney were homogenized separately with phosphate-buffered saline (PBS) using a Potter-Elvehjem glass homogenizer and used immediately after. For the measurements of the oxidative stress parameters, the brain, liver and kidney were homogenized separately with (1:10 $\mathrm{w} / \mathrm{v}$ ) of $20 \mathrm{mM}$ sodium phosphate and $140 \mathrm{mM}$ $\mathrm{KCl}$ buffer (pH 7.4) using a Potter-Elvehjem glass homogenizer and centrifuged at $800 \mathrm{x}$ g for $10 \mathrm{~min}$ at $4^{\circ} \mathrm{C}$. The supernatant was collected and frozen at $-70^{\circ} \mathrm{C}$ for no more than 1 week until determination of the parameters of oxidative stress. Protein content was determined by the method described by Lowry et al. (1951) using bovine serum albumin as standard

\section{THIOBARBITURIC ACID REACTIVE}

SPECIES CONTENT IN TISSUE

To determine oxidative damage in lipid, we measured the formation of Thiobarbituric acid reactive species (TBARS) during an acid-heating reaction, as previously described by Draper and Hadley (1990). The samples were mixed with $1 \mathrm{ml}$ of trichloroacetic acid $10 \%$ and $1 \mathrm{ml}$ of thiobarbituric acid $0.67 \%$, and then heated in a boiling water bath for $30 \mathrm{~min}$. Malondialdehyde equivalents were determined in tissue and in submitochondrial particles of the rat brain spectrophotometrically by the absorbance at $532 \mathrm{~nm}$. 


\section{CARBONYLS PROTEIN FORMATION}

The oxidative damage to proteins was assessed by the determination of carbonyl groups content based on the reaction with dinitrophenylhydrazine (DNPH), as previously described by Levine et al. (1994). Proteins were precipitated by the addition of $20 \%$ trichloroacetic acid and were redissolved in DNPH. The absorbance was monitored spectrophotometrically at $370 \mathrm{~nm}$.

\section{COMET ASSAY}

The alkaline comet assay was performed as described by Singh et al. (1988) with the modifications suggested by Tice et al. (2000). The extent of the DNA damage was assessed using Collins'visual classification method (2004). Images of 100 randomly selected cells were analyzed per individual. Cells were scored visually into five classes, according to tail size and shape (from undamaged - 0 , to maximally damaged - 4 ), and a value (Damage Index) was assigned to each comet according to its class. Damage index thus ranged from 0 (completely undamaged: 100 cells $\times 0$ ) to 400 (with maximum damage: 100 cells $\times 4$. The Damage Frequency (\%) was calculated based on the percentage of damaged cells ( $0-100 \%)$. International guidelines and recommendations for the comet assay consider that visual scoring of comets is a well-validated evaluation method. It has a high correlation with computer-based image analysis. In addition, according to Tice et al. (2000) researchers the apoptosis/necrosis damage cell cannot be assessed by Comet Assay technique, thus, the cells that do not present the format required by classification of the Comet Assay were excluded of the slides reading.

\section{STATISTICAL ANALYSIS}

Data were analyzed using a one-way analysis of variance (ANOVA), followed by Tukey test when $\mathrm{F}$ was significant. The data are expressed as mean \pm standard deviation. All analyses were performed using the Statistical Package for the Social Sciences (SPSS) software.

\section{RESULTS}

Our results demonstrated that 7 and 14 days of PQ administration increase DNA damage frequency and index in brain and liver (Figures 1 and 2, respectively), whereas 21 days of $\mathrm{PQ}$ administration increased DNA damage frequency and index only in brain (Figure 3). On the other hand, CQ increased DNA damage frequency and index in kidney after 7 and 14 days of administration, but was not altered after 21 days. In liver and brain, CQ administration for 14 and 21 days increased DNA damage frequency and index (Figures 2 and 3,
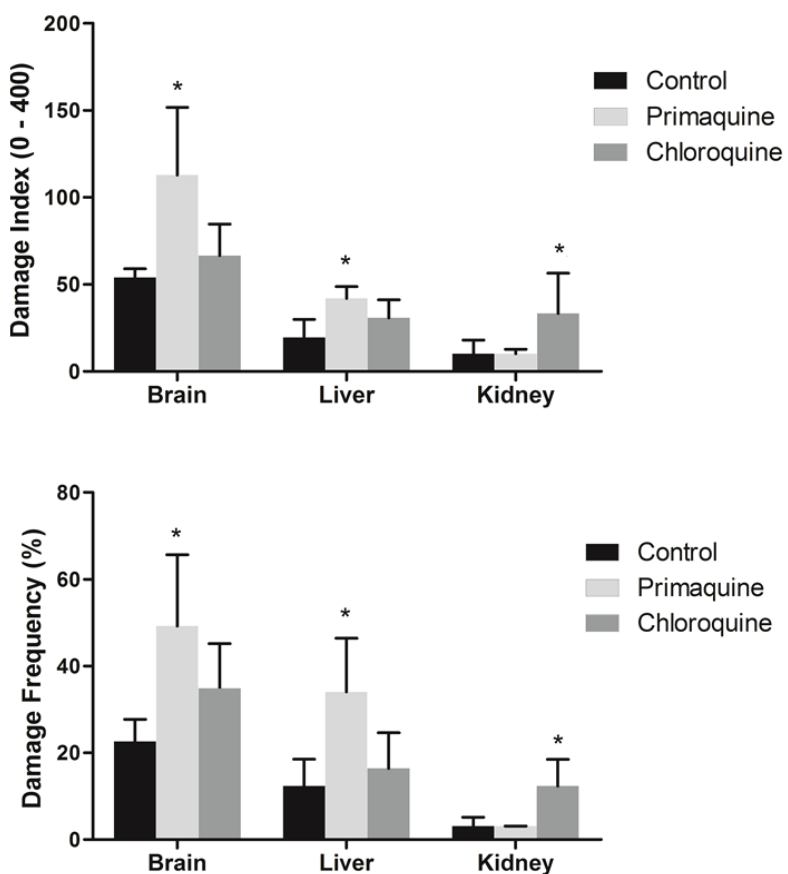

Figure 1 - Effect of 7days of administration of primaquine and chloroquine on frequency and index of DNA damage in brain, liver and kidney of rats ( $n=7$ per group). Data were analyzed by one-way analysis of variances followed by the Tukey test when $\mathrm{F}$ was significant. Values are expressed as mean \pm S.D. $* p<0.05$ compared to control group. 

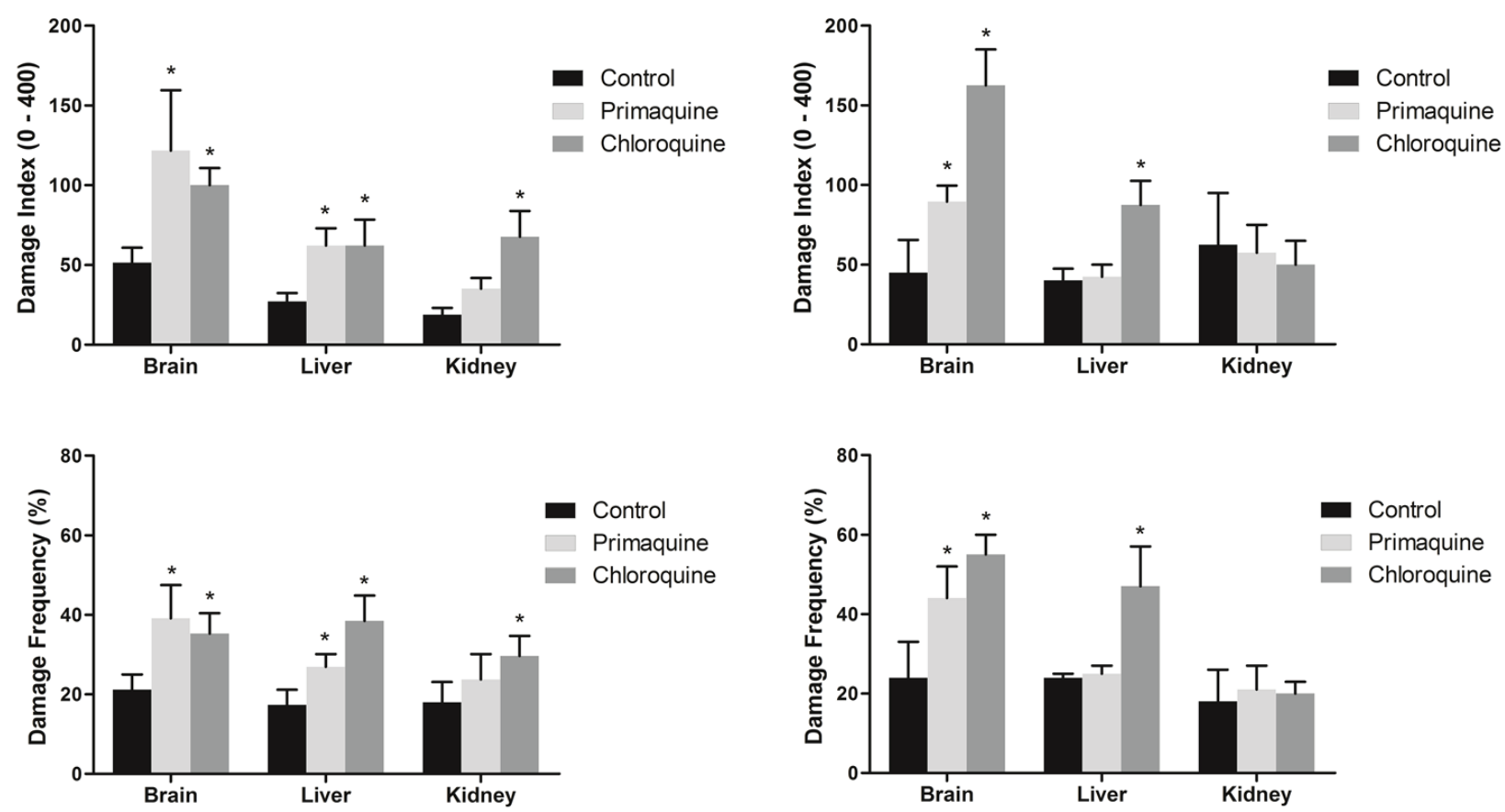

Figure 2 - Effect of 14 days of administration of primaquine and chloroquine on frequency and index of DNA damage in brain, liver and kidney of rats $(\mathrm{n}=7$ per group). Data were analyzed by one-way analysis of variances followed by the Tukey test when $\mathrm{F}$ was significant. Values are expressed as mean \pm S.D. ${ }^{*} \mathrm{p}<0.05$ compared to control group.

respectively), whereas 7 days of CQ administration did not alter DNA damage.

Lipid peroxidation products (TBARS) are increased after 7 days of CQ treatment in the kidney, whereas PQ increases TBARS levels after 14 days. However, 21 days of CQ treatment decreased TBARS levels in brain, while the TBARS levels were not altered in the liver after CQ and PQ treatment (Figure 4).

Administration of CQ decreased protein markers of oxidative stress (protein carbonyls) in the liver after 7 and 14 days of treatment, whereas PQ decreases protein carbonyls in the liver only after 7 days. However, in the brain, the protein carbonyls were decreased after 7 and 21 days of CQ treatment, while after 14 days of CQ and PQ treatment increase protein carbonyls. Lastly, in the kidney, CQ treatment for 14 days increases protein carbonyls (Figure 5).

Figure 3 - Effect of 21 days of administration of primaquine and chloroquine on frequency and index of DNA damage in brain, liver and kidney of rats $(n=7$ per group). Data were analyzed by one-way analysis of variances followed by the Tukey test when F was significant. Values are expressed as mean \pm S.D. ${ }^{*} p<0.05$ compared to control group.

\section{DISCUSSION}

The present investigations were undertaken to find out if long-term administration of antimalarials for treatment, management and prophylaxis could have adverse effects on the oxidative damage. Inhibition of the mitochondrial functions and oxidative stress in Plasmodium by antimalarials has been suggested as one of the possible mechanism of action of antimalarials (Bhattacharyya et al. 1983, Krungkrai et al. 1999, Lanners 1991, Katewa and Katyare 2004). Hence we focused our attention to find out if prolonged treatment with antimalarials induce oxidative stress and cause DNA damage in liver, kidney and brain.

Bhattacharyya et al. (1983) demonstrated that administration of CQ increase in NADPH-induced lipid peroxidation and normalization or a decrease in lipid peroxidation, follows the daily treatment 

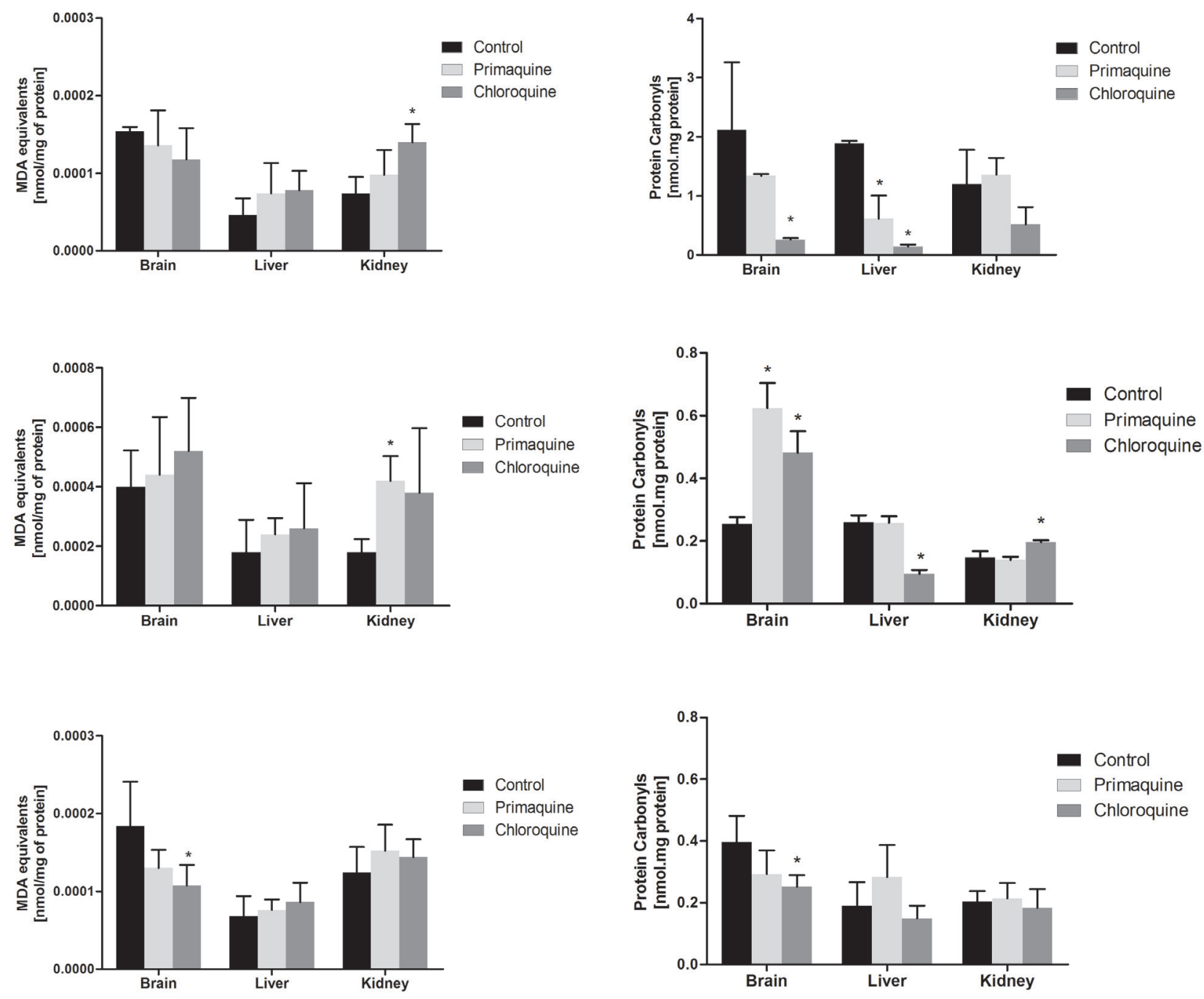

Figure 4 - Effect of 7, 14 and 21 days of administration of primaquine and chloroquine on thiobarbituric acid reactive species levelsin brain, liver and kidney of rats ( $n=7$ per group). Data were analyzed by one-way analysis of variances followed by the Tukey test when F was significant. Values are expressed as mean \pm S.D. $* p<0.05$ compared to control group.

schedule when the destabilizing effect of CQ is no longer demonstrable. However, PQ toxicity is thought to be due to redox-active metabolites that generate ROS. Additionally, Katewa and Katyare (2004) demonstrated that prolonged use of antimalarials result in severe impairment in energy metabolism, metabolic activities and alters the mitochondrial lipid/phospholipid composition. In this context, it has been demonstrated that the

Figure 5 - Effect of 7, 14 and 21 days of administration of primaquine and chloroquine on carbonyls protein formation levels in brain, liver and kidney of rats ( $n=7$ per group). Data were analyzed by one-way analysis of variances followed by the Tukey test when F was significant. Values are expressed as mean \pm S.D. $* p<0.05$ compared to control group.

inhibition the mitochondrial respiratory chain result in the generation of reactive species, forming a cyclic phenomenon (Adam-Vizi 2005). Thus, that oxidative damage after administration of antimalarials can be due impartment in energy metabolism.

In the present study, we showed that PQ and CQ induce DNA damage after 7,14 and 21 days of treatment. However, these effects were dependent 
of antimalarial drug and the structure analyzed. DNA damage can activate several intracellular signaling pathways such as the phosphorylation of p53 at the serine and threonine residues, leading to cell apoptosis (Evan and Littlewood 1998, Culmsee and Mattson 2005). It should be emphasized that DNA is a particularly important target for oxidation generating several classes of products (single- and double-strand breaks), inter/ intra-strand cross-links, DNA-proteins cross-links and sugar fragmentation products. These products can elicit mutations, microsatellite instability and loss of heterozygosity, chromosomal aberrations, cytotoxicity and neoplasic growth (Cooke et al. 2006).

It has been shown that free radicals can initiate DNA damage (Culmsee and Mattson 2005, Cooke et al. 2006) which under certain circumstances can lead to DNA mutation. In this context, several reports in the literature suggest that drugs used to treat malaria, such as chloroquine and primaquine) lead to oxidative stress, particularly in erythrocytes (Bolchoz et al. 2002, Baird and Hoffman 2004, Becker et al. 2004). In agreement with these results, we verified that protein carbonyl content, an index of protein oxidation, was significantly enhanced in brain after 14 days of CQ and PQ treatment, and in kidney after 14 days of CQ treatment. Additionally, we also showed a significant increase in TBARS levels, an index of lipid oxidation, in the kidney after 7 days of CQ treatment and in the liver after of 14 days of PQ treatment. Moreover, we also showed that CQ and PQ decrease protein carbonyl content and TBARS levels after 7 and 21 days of treatment. Suggesting that treatment for 14 days resulted in the increased of oxidative damage, but treatment for 21 days cause a restoration of lipid peroxidation and protein carbonyls formation. The alterations in the levels of TBARS and protein carbonyls may be represent both responses to antimalarial treatment as well as compensatory mechanism at latter stages. Corroborating this hypothesis, it has been reported that the metabolites of the antimalarial drugs could have different antimalarial and toxicity properties (Leslie 1990, Constantino et al. 1999). It is also possible that the antimalarials effects may be restricted to the tissue, since studies have showed that CQ and PQ accumulate in certain tissues and organs to very high levels (Adelusi and Salako 1982, Hostetler et al. 1985). Musabayane in your studies have shown that CQ alter kidney structure and affect renal sodium excretion (Musabayane 1993, 1994). Moreover, a report using CQ alone reported a stabilizing effect of the drug on the hepatocytes (Achudume 2009). Interestingly, Bowman et al. (2005) showed that the 5-HPQ increases generation of ROS, and this was not associated with the onset of lipid peroxidation or an alteration in phosphatidylserine asymmetry. Instead, 5-HPQ induced oxidative injury to the erythrocyte cytoskeleton, suggesting that cytoskeletal protein damage underlies the process of removal of erythrocytes exposed to 5-HPQ. Thus, it is possible that CQ and PQ, acting directly or indirectly, could alter antioxidant status and make certain organs more susceptible to the effects of oxidative stress.

CQ and PQ provoke molecular events that are not well characterized. Our results showed that effects of CQ and PQ on oxidative stress parameters were dependent on the treatment regimen, whereas that DNA damage was observed in all treatment protocols. Thus, based on our results, we suggest that the DNA damage observed after 14 days of treatment may be associated with oxidative stress induced by CQ and PQ. Our hypothesis corroborate a study published by Farombi (2006) demonstrating that genotoxicity of CQ in rat liver cells might involve ROS and that free radical scavengers may elicit protective effects in these cells. However, other mechanisms may be involved in this damage, since CQ and PQ caused DNA damage after 7 and 21 days of treatment. Indeed, Michael and Williams (1974) showed that CQ inhibited the repair of DNA damage produced in cultured rat liver cells by methyl methanesulfonate.

In conclusion, the results of our present studies show that prolonged treatment with antimalarial 
can adversely affect the DNA damage. However, at this stage it is not possible to comment on whether the effects observed are the effect per se due to antimalarial actions or are to be attributed to the actions of their metabolites or to both.

\section{ACKNOWLEDGMENTS}

This research was supported by grants from Programa de Pós-graduação em Ciências da Saúde Universidade do Extremo Sul Catarinense(UNESC) and Conselho Nacional de Desenvolvimento Científico e Tecnológico (CNPq).

\section{RESUMO}

A primaquina e cloroquina são utilizadas para o tratamento da malária; evidências da literatura sugerem que estes fármacos podem induzir o estresse oxidativo. Neste estudo investigou-se os efeitos da primaquina e cloroquina sobre danos oxidativo e ao DNA no cérebro, fígado e rim de ratos após 7, 14 e 21 dias de administração. Nossos resultados demonstraram que a primaquina causou dano ao DNA no cérebro após 7, 14 e 21 dias, e no fígado após 7 e 14 dias. Além disso, a primaquina aumentou os níveis de TBARS no rim e a carbonilação de proteínas no cérebro após 14 dias, e diminuiu a carbonilação de proteínas no fígado após 7 dias. Enquanto que a cloroquina causou dano ao DNA no rim após 7 e 14 dias, e no fígado e cérebro após 14 e 21 dias, aumentou os níveis de TBARS após 7 dias no rim, e reduziu os níveis de TBARS no cérebro após 21 dias. Além disso, diminuiu a carbonilação de proteínas no fígado após 7 e 14 dias, e no cérebro após 7 e 21 dias. Entretanto, o tratamento com cloroquina durante 14 dias aumentou a carbonilação de proteínas no cérebro e rim. Em conclusão, estes resultados mostraram que o tratamento prolongado com antimaláricos pode afetar adversamente o DNA.

Palavras-chave: primaquina, cloroquina, dano oxidativo, dano ao DNA, antimaláricos.

\section{REFERENCES}

ACHUDUME AC. 2009. The influence of chloroquine administration on antioxidant levels, oxidant marker and total cholesterol in Wistar rats. Biol Med 1: 39-43.
ADAM-VIZI V. 2005. Production of reactive oxygen species in brain mitochondria: contribution by electron transport chain and non-electron transport chain sources. Antioxid Redox Signal 7: 1140-1149.

ADELUSI SA AND SALAKO LA. 1982. Kinetics of the distribution and elimination of chloroquine in the rat. Gen Pharmacol 13: 433-437.

BACK DJ, PURBA HS, Staiger C, ORME ML AND BRECKENRIDGE AM. 1983. Inhibition of drug metabolism by the antimalarial drugs chloroquine and primaquine in the rat. Biochem Pharmacol 32: 257.

BAIRD JK, FRYAUFF DJ AND HOFFMAN SL. 2003. Primaquine for prevention of malaria intravelers. Clinical Infectious Diseases 37: 1659-1667.

BAIRD JK AND HOFFMAN SL. 2004. Primaquine therapy for malaria. Clin Infect Dis 39: 1336-1345.

BAREnNes H, BALima-Koussoube $\mathrm{T}$, NAgot $\mathrm{N}$, Charpentier JC AND PUSSARD E. 2006. Safety and efficacy of rectal compared with intramuscular quinine for the early treatment of moderately severe malaria in children: randomised clinical trial. Br Med J 332: 1055 1057.

Becker K, Tilley L, Vennerstrom JL, Roberts D, ROGERSON S AND GINSBURG H. 2004. Oxidative stress in malaria parasite-infected erythrocytes: host-parasite interactions. Int J Parasitol 34: 163-189.

BHATTACHARYYA B, CHATTERJEE TK AND GHOSH JJ. 1983. Effects of chloroquine on lysosomal enzymes, NADPHinduced lipid peroxidation, and antioxidant enzymes of rat retina. Biochem Pharmacol 32: 2965-2968.

BOLCHOZ LJC, MORROW DJ, JOLLOW DJ AND MCMILLAN DC. 2002. Primaquine-induced hemolytic anemia: effect of 6-methoxy-8-hydroxylaminoquinoline on rat erythrocyte sulfhydryl status, membrane lipids, cytoskeletal proteins, and morphology. J Pharmacol Exp Ther 303: 141-148.

BOWMAN ZS, MORROW JD, JOLLOW DJ AND MCMILLAN DC. 2005. Primaquine-induced hemolytic anemia: role of membrane lipid peroxidation and cytoskeletal protein alterations in the hemotoxicity of 5-hydroxyprimaquine. $\mathrm{J}$ Pharmacol Exp Ther 314: 838-845.

BRAY PG AND WARD SA. 1993. Malaria Chemotherapy: Resistance to quinoline containing drugs in Plasmodium falciparum. FEMS Microbiol Lett 113: 1-8.

COLLINS AR. 2004. The comet assay for DNA damage and repair: principles, applications, and limitations. Mol Biotechnol 26: 249-261.

CONSTANTINO L, PAIXAO P, MOREIRA R, PORTELA MJ, DO ROSARIO VE AND ILEY J. 1999. Metabolism of primaquine by liver homogenate fractions. Evidence for monoamine oxidase and cytochrome P450 involvement in the oxidative deamination of primaquine to carboxyprimaquine. Exp Toxicol Pathol 51: 299-303. 
COOKE MS, OLINSKI R AND Evans MD. 2006. Does measurement of oxidative damage to DNA have clinical significance? Clin Chim Acta 365: 30-49.

CulmseE C AND MATTSON MP. 2005. p53 in neuronal apoptosis. Biochem Biophys Res Commun 331: 761-777.

De Duve C, De Barsy T, Poole B, Trouet A, Tulkens P AND VAN HOOF F. 1974. Lysosomotropic agents. Biochem. Pharmacol 23: 2495-2568.

DEGROOT PQ, EIFERINK RQ, HOLLEMANS M, KHAND M AND TAGER JM. 1981. Activation of B galactosidase in cultured human skin fibroblast. Exp Cell Res 136: 327333.

DRAPER HH AND HADLEY M. 1990. Malondialdehyde determination as index of lipid peroxidation. Methods Enzymol 186: 421-431.

EMEROLE GO AND THABREW MI. 1983. Changes in some rat hepatic microsomal components induced by prolonged administration of chloroquine. Biochem Pharmacol 32: 3005-3009.

EVAN G AND LITTLEWOOD T. 1998. A matter of life and cell death. Science 281: 1317-1322.

FAROMBI EO. 2006. Genotoxicity of chloroquine in rat liver cells: protective role of free radical scavengers. Cell Biol Toxicol 22: 159-167.

FOLEY M AND TILLEY L. 1998. Quinolineantimalarials: mechanisms of action and resistance and prospects for new agents. Pharmacol Ther 79: 55-87.

Hostetler KY, ReAsor M AND YAZAKI PJ. 1985. Chloroquine-induced phospholipid fatty liver. Measurement of drug and lipid concentrations in rat liver lysosomes. J Biol Chem 260: 215-219.

KAIN KC AND KEYSTONE JS.1998. Malaria in travelers. Epidemiology, disease and prevention. Infect Dis Clin N Am 12: 267-284.

KATEWA SD AND KATYARE SS. 2004. Treatment with Antimalarials Adversely Affects the Oxidative Energy Metabolism in Rat Liver Mitochondria. Drug and Chem Toxic 27: 41-53.

KRUNGKRAi J, BURAT D, KUdAN S, KRUNGKRAI S AND PRAPUNWATTANA P. 1999. Mitochondrial oxygen consumption in asexual and sexual blood stages of the human malarial parasite, Plasmodium falciparum. Southeast Asian J Trop Med Public Health 30: 636-642.

KUMAR S AND BANDYOPADHYAY U. 2005. Free heme toxicity and its detoxification systems in human. Toxicol Lett 157: 175-188.

LANNERS HN. 1991. Effect of the 8-aminoquinoline and primaquine on culture-derived gametocytes of the malaria parasite Plasmodium falciparum. Parasitol Res 77: 478481.

LESLIE JR TW. 1990. Drugs used in the chemotherapy of protozoal infections malaria. In: Gilmann AG, Rall TW, Nies AS and Taylor P (Eds), The Pharmacological Basis of
Therapeutics, $8^{\text {th }}$ ed. Pergamon Press: New York, p. 959997.

LEVINE RL, Williams JA, StADTMAN ER, SHACTER E. 1994. Carbonyl assays for determination of oxidatively modified proteins. Methods Enzymol 233: 346-357.

LOWRY OH, ROSEBOUGH NG, FARR AL AND RANDALL RJ. 1951. Protein measurement with the Folin phenol reagent. J BiolChem 193 :265-275.

MACKENZIE AH. 1990. Pharmacological actions of 4-aminoquinoline compounds. Am J Med, July 18, 1983.

MichaEL RO AND Williams GM. 1974. Chloroquine inhibition of repair of DNA damage induced in mammalian cells by methyl methanesulfonate. Mutat Res 25: 391-396.

MURRAY M. 1984. In vitro effects of quinoline derivatives on cytochrome P450 and aminopyrine N-demethylase activity in rat hepatic microsomes.Biochem Pharmacol 33: 3277-3281.

MusABAyAne CT, NDHLOVU CE AND BALMENT RJ. 1994. The effects of oral chloroquine administration on kidney function. Renal Fail 16: 221-228.

Musabayane CT, Ndhlovu CE, Mamutse G, Bwititi P AND BALMENT RJ. 1993. Acute chloroquine administration increases renal sodium excretion. J Trop Med Hyg 96: 305-310.

NA-BANGCHANG K AND KARBWANG J. 2009. Current status of malaria chemotherapy and the role of pharmacology in antimalarial drug research and development.Fundam Clin Pharmacol 23: 387-409.

NGAHA EO. 1982. Some biochemical changes in the rat during repeated chloroquine administration. Toxicol Lett 10: 145149.

RIFKIND RA.1966. Destruction of injured red cells in vivo. Am J Med 41: 711-723.

SHANKS GD, KAIN KC AND KEYSTONE JS. 2001. Malaria chemoprophylaxis in the age of drug resistance II. Drugs that may be available in the future. Clin Infect Dis 33: 381-385.

SINGH N, MCCOY M, TICE R AND SCHNEIDER E. 1988. A simple technique for quantification of low levels of DNA damage in individuals cells. Exp Cell Res 175: 184-191.

SLATER AFG. 1993. Choroquine: Mechanism of drug action and resistance in Plasmodium falciparum. Pharmacol Ther 57: 203.

SOLOMON VR AND LEE H. 2009. Chloroquine and its analogs: a new promise of an olddrug for effective and safe cancer therapies. Eur J Pharmacol 625: 220-233.

SRIVASTAVA P, PURI SK, DUTTA GP AND PANDEY VC. 1993. Effect of the antimalarial agents primaquine and (N'-3-acetyl-4-5-dihydro-2-furanyl)-N4-(6-methoxy-8quinolinyl)1,4-pent ane-diamine on oxidative stress and antioxidant defences in mice. Biochem Pharmacol 46: 1859-1860. 
STAINES HM AND KRISHNA S. 2012. Treatment and prevention of malaria:antimalarial drug chemistry, action and use. Springer Basel AG: 1-315.

SUMMERFIELD M AND TUDHOPE GR. 1978. Studies with primaquine in vitro: superoxide radical formation and oxidation of haemoglobin. Br J Clin Pharmacol 6: 319323.

THABREW MI AND IOANNIDES C. 1984. Inhibition of rat hepatic mixed function oxidases by antimalarial drugs: Selectivity for cytochromes P450 and P448. Chem. Biol. Int. 51:285-294.

THABREW MI, NASHIRU TO AND EMEROLE GO. 1985. Drug induced alterations in some rat hepatic microsomal components: a comparative study of four structurally different antimalarials. Comp Biochem Physiol C 81: 133-138.
Tice RR, Agurell E, Anderson D, Burlinson B, HARTMANN A, KOBAYASKI H, MIYAMOL Y, ROJAS E, RYU JC AND SASAKI YF. 2000. Single cell gel/comet assay: Guidelines for in vitro and an in vivo genetic toxicological testing. Environ. Mol Mutagen 35: 206-221.

VASQUEZ-VIVAR J AND AUGUSTO O. 1992. Hydroxylated metabolites of the antimalarial drug primaquine.Oxidat. and red. cycli. J Biol Chem 267: 6848-6854.

WAGENER FA, VOLK HD, WILLIS D, ABRAHAM NG, SOARES MP, ADEMA GJ AND FIGDOR CG. 2003. Different faces of hemeoxygenase system in inflammation. Pharmacol Rev 55: 551-571.

WHO - World Health Organization. 2013. Geneva, Switzerland. World malaria report, $284 \mathrm{p}$. 